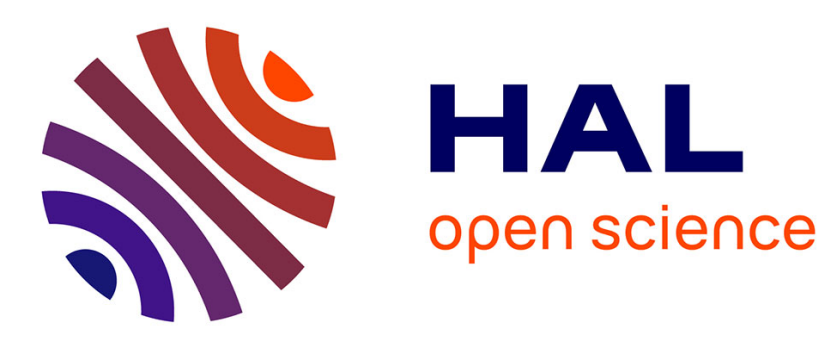

\title{
Corona Discharges in Atmospheric Air Between a Wire and Two Plates
}

Philippe Bérard, Deanna A. Lacoste, C. Laux

\section{To cite this version:}

Philippe Bérard, Deanna A. Lacoste, C. Laux. Corona Discharges in Atmospheric Air Between a Wire and Two Plates. IEEE Transactions on Plasma Science, 2011, 39 (11), pp.2248-2249. 10.1109/TPS.2011.2162854 . hal-00669366

\section{HAL Id: hal-00669366 https://hal.science/hal-00669366}

Submitted on 22 Feb 2012

HAL is a multi-disciplinary open access archive for the deposit and dissemination of scientific research documents, whether they are published or not. The documents may come from teaching and research institutions in France or abroad, or from public or private research centers.
L'archive ouverte pluridisciplinaire HAL, est destinée au dépôt et à la diffusion de documents scientifiques de niveau recherche, publiés ou non, émanant des établissements d'enseignement et de recherche français ou étrangers, des laboratoires publics ou privés. 


\title{
Corona Discharges in Atmospheric Air between a Wire and two Plates
}

\author{
Philippe Bérard, Deanna A. Lacoste and Christophe O. Laux
}

\begin{abstract}
The corona discharge obtained in atmospheric air between a wire and two plates is presented. For the configuration studied and the voltage applied, the current is steady for the positive corona and exhibits Trichel pulses in the negative corona. The positive corona produces a homogeneous blue halo around the wire whereas the negative discharge produces evenly spaced spots on the wire surface. We verified the analytic prediction that the ionic wind varies as the square root of the mean current
\end{abstract}

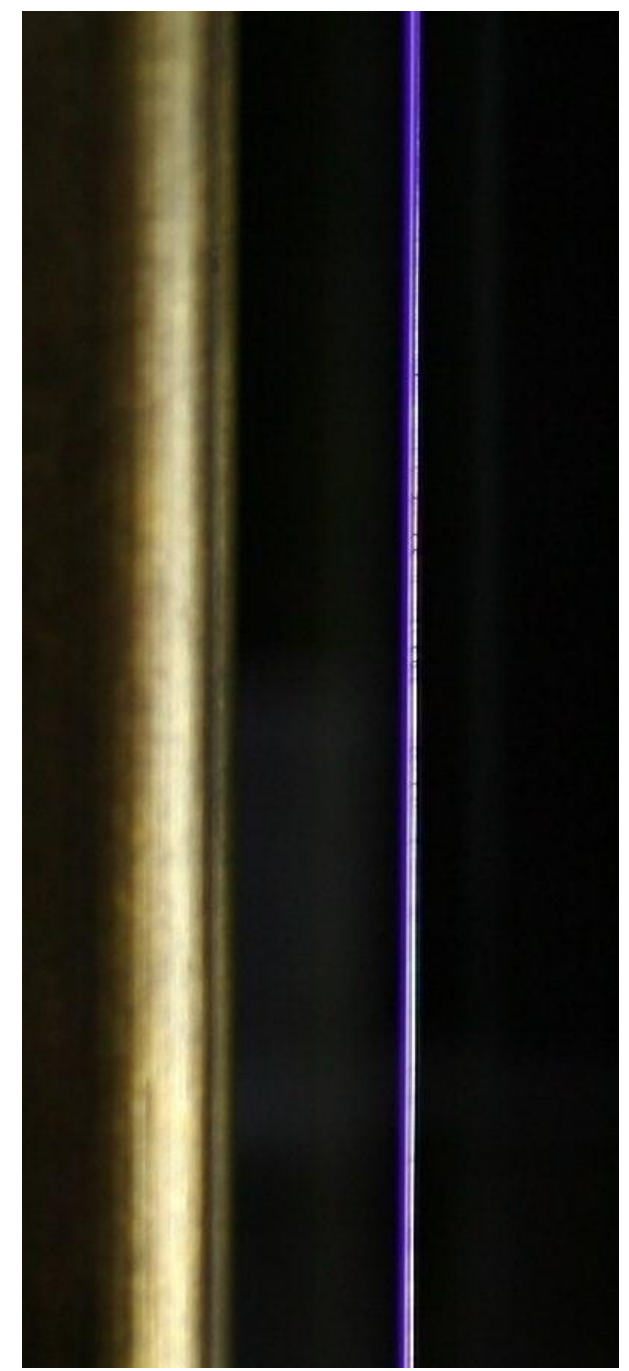

(a) for both the positive and negative polarities. The measured ionic wind produced by the positive corona is higher than for the negative corona. We propose an explanation for the difference of velocity between polarities.

Index Terms: atmospheric-pressure plasmas, corona, glow discharges, electrohydrodynamics, plasma measurements

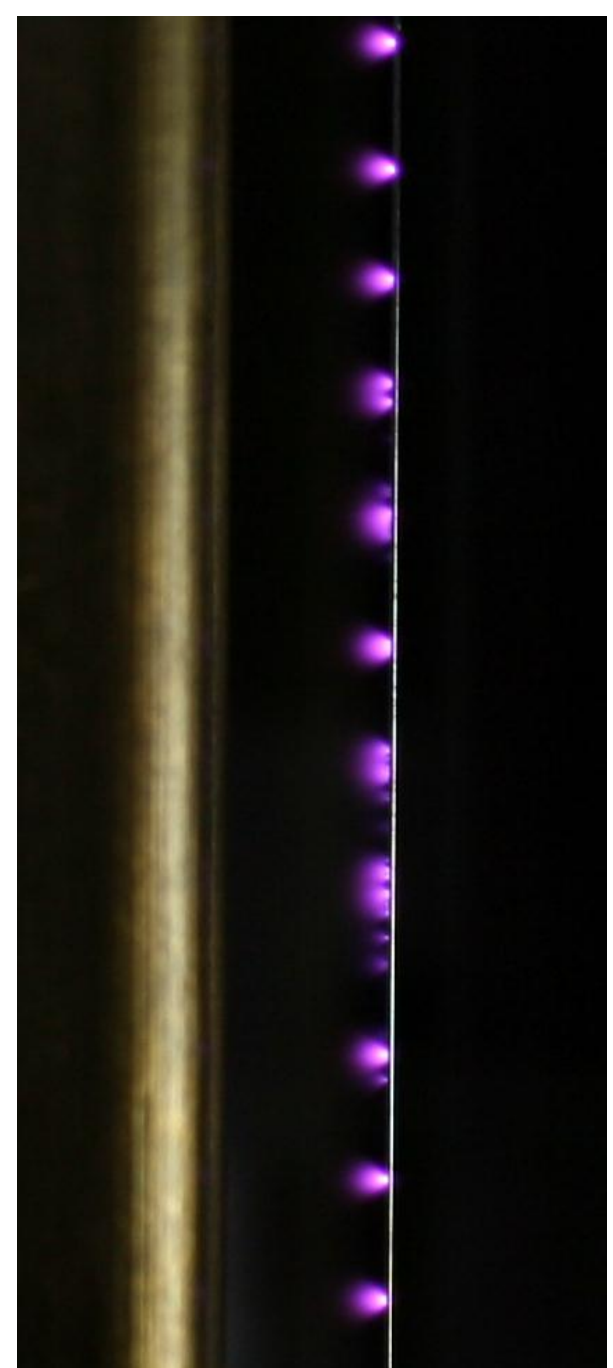

(b)

Fig. 1. Corona Discharges between a high potential wire and two grounded plates in air at atmospheric pressure and ambient temperature. (a) positive corona $(\mathrm{V}=14.2 \mathrm{kV}, \mathrm{I}=1.5 \mathrm{~mA})$, (b) negative corona $(\mathrm{V}=-10.5 \mathrm{kV}, \mathrm{I}=-1.3 \mathrm{~mA})$

Manuscript received 30 November 2010; revised xxx.

The authors are with the Ecole Centrale Paris, EM2C Laboratory, CNRS UPR288, Grande Voie des Vignes, 92290 Châtenay-Malabry. Philippe Bérard's current address is philippe.berard@renault.com. Work was supported by Délégation Générale pour l'Armement and CNRS.

Publisher Identifier S XXXX-XXXXXXX-X 
The ionic wind created by a corona discharge or a dielectric barrier discharge on the boundary layer of an airfoil has interesting potential applications for the purpose of reducing drag, controlling the transition to turbulence, and for flow actuation. For example, reference [1], has successfully demonstrated boundary layer reattachment of a low-speed flow on a surface. The work presented here is part of a parametric study [2]-[3] on a simple reference configuration to quantify the effect of the discharge and geometry on the flow velocity. We focus on the differences between the positive and negative corona discharges.

Our experimental setup is composed of a thin wire and two parallel plates, $20 \mathrm{~cm}$ in length, in air at atmospheric pressure and ambient temperature (see schematic on fig. 2). The wire is brought to a high DC voltage adjustable up to 20 $\mathrm{kV}$ (positive or negative polarity) with a FUG 140-20000 power supply, whereas the plates are connected to ground. We measured the flow velocity using hot wire anemometry.

The positive discharge (Fig. 1a) produces a homogeneous blue halo in the vicinity of the surface of the high potential wire. Its radial extension is about a tenth of millimeter. Its brightness increases with current and voltage. Electrical measurements show that both the current and voltage are steady. In contrast, the negative discharge (Fig. 1b) creates fairly evenly spaced luminous discharge cones between the wire and the plates. These cones are visually stable and produce an acute whistle. Their number and their brightness increase with current and voltage. Oscilloscope traces show current peaks on top of a DC current component, showing the pulsed nature of the negative discharge. These observations are similar to those reported in [4]. The mechanism of the discharge is not the same depending on the polarity, so it is interesting to compare the ionic wind velocity measured for each case.

Depending on the polarity, the ions responsible for the ionic wind are not the same: positive ions in the positive discharge and negative ions in the negative discharge. With the setup shown in Fig. 2, we verified that, for a given mean current, the flow velocity is higher for the positive corona than for the negative corona. Although the spark appears for a higher mean current in the case of the negative discharge, the velocity obtained with the positive corona discharge is always around $40 \%$ higher than that obtained with the negative discharge. Such a difference in behavior cannot be explained by the presence of different ions in the two discharges, because the mobilities of the main positive and negative ions in air are comparable [5]. The different velocities in the positive and negative coronas can be explained as follows. For the negative discharge, the velocity is plotted as a function of the mean current, i.e. an average of the DC and pulsed components. However, it was shown in [6] that the ionic wind produced during current peaks is significantly lower than that produced between pulses. As a result, when plotted as a function of the mean current, the velocity obtained with the negative corona should be lower than in the positive corona case.

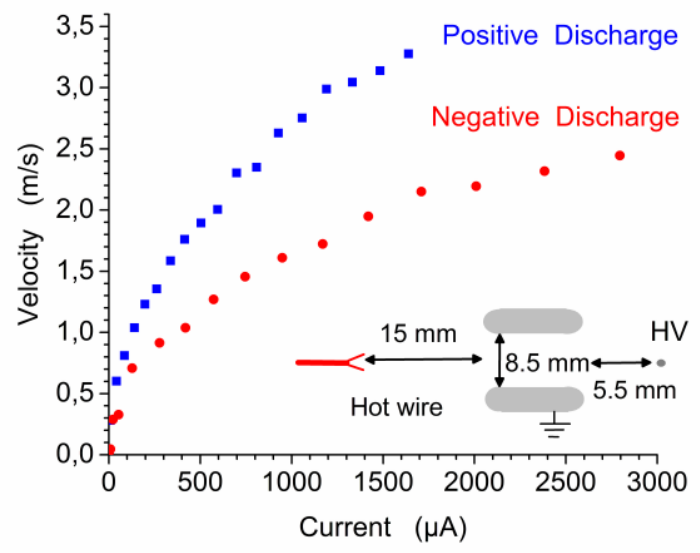

Fig. 2. Flow velocity measured with a hot wire device for the positive and the negative discharges in a wire- 2 plate configuration.

In conclusion, the positive and negative discharges produce significantly different configurations of coronas, with a significantly higher ionic wind in the positive corona. A detailed parametric study of the ionic wind in positive coronas is presented in Refs. [2]-[3].

\section{REFERENCES}

[1] L. Léger, E. Moreau, and G. Touchard, "Electrohydrodynamic Airflow Control along a Flat Plate by a DC Surface Corona Discharge - Velocity Profile and Wall Pressure Measurements," AIAA-2002-2833, $1^{\text {st }}$ Flow Control Conference, St. Louis, Missouri, June 2002.

[2] P. Bérard, "Etude du vent ionique produit par décharge couronne à pression atmosphérique pour le contrôle d'écoulement aérodynamique," Ph.D. dissertation, Ecole Centrale Paris, France, 2008.

[3] P. Bérard, D. A. Lacoste and C. O. Laux, "Measurements and Simulations of the ionic wind produced by a DC corona discharge between cylindrical wires," AIAA-2007-4611, AIAA Plasmadynamics and Lasers Conf., Miami, Florida, June 2007.

[4] G. W. Trichel, "The mechanism of the negative point to plane corona near onset," Phys. Review 54, pp. 1078-1086, 1938

[5] H. W. Ellis, R. Y. Pai, E. W. McDaniel, E. A. Mason, and L. A. Viehland, "Transport properties of gaseous ions over a wide energy range," Atomic Data and Nuclear Data Tables 17, pp. 177-210, 1976.

[6] J. P. Boeuf, Y. Lagmich, T. Callegari and L. C. Pitchford, "Electrohydrodynamic force and acceleration in surface discharges," AIAA 2006-3574, 37 th $^{\text {AIAA Pasmasdynamics and }}$ Lasers Conference, San Francisco, 5-8 June 2006. 